\title{
Request forms for extended campus library services
}

\author{
By Therese D. Baker
}

\section{Using the right form improves information service}

$n$ response to the needs of an ever-increasing number of students enrolled in courses away from the main campus in Bowling Green, Western Kentucky University (WKU) Libraries initiated Extended Campus Library Services (ECLS) in the fall of 1987. Extended campus students may call a toll-free number to order copies of journal articles and books from the circulating collection to be sent to them by mail, or by courier to the Glasgow Campus Library (a branch of WKU Libraries, about 35 miles away), or to the Owensboro Center, 75 miles from the main campus. Telefacsimile service is also available. Since the inception of ECLS response has been enthusiastic: document deliveries have averaged a total of well over 10,000 items per year.

The ECLS on-campus staff consists of one full-time faculty librarian, one 20-hour-per-week library assistant, and student assistants assigned for 30-42 hours per week. Staff in the adjacent Circulation Services desk area serve as backup for answering the toll-free extension phone. Because reference assistance is included in ECLS upon request, librarians from other areas in the university libraries participate in fulfilling extended campus students' research needs.

Personnel in the Glasgow Campus Library and in Owensboro also take requests from students. With so many different persons handling requests, it early became evident that a clear and comprehensive document to facilitate communication among all involved had to be devised. Designed by former colleague Dana Boden, the EClS request form in its present format evolved after several rudimentary ver- sions had been in use, and staff input sought (see figure 1).

At the beginning of each semester, a twopage information sheet outlining ECLS in detail is mailed to every WKU student registered for extended campus courses. With the aid of this handout, callers should be prepared to provide the information that will be requested of them when they call. The many spaces to be filled in on the ECLS request form prompt the staff answering the phone to remember to ask the right questions.

Key elements on the form include: reference assistance $\log \#$, date, time, name, social security number, address, home phone, work phone, time zone, subject or topic, location of course, course, professor, staff member taking request, date results needed by, and how to send materials by (mail, courier, fax, other). Lines for bibliographic citations to ten journal articles and five books follow the preliminary information to be filled in on the front of the form. Unless otherwise specified, document deliveries are fulfilled in chronological order as requests are received. As seemingly inconsequential a detail as recording the time of day when a request was made can be crucial to placing requests in priority order, as well as to scheduling staff to answer the toll-free phone. Students' names and social security numbers are checked against a list to verify eligibility for service. The ECLS form also facilitates work flow. As student assistants carry the forms with them to retrieve journals and books from various floors of the library, notations are made in the margins of the forms about availability. Any incomplete requests are then placed in stacks for additional work and completion. A photocopy of the request form, notes denoting progress towards completion included, acts as a packing slip when it accompanies document 
deliveries. All request form originals are kept on permanent file in the ECLS office.

Monthly statistics are compiled from the request forms. Not only are the course number, location of class, and professor's name required to verify legitimacy of the request, but statistics of use by classes in specific disciplines, different grade levels, geographic locations, and by certain professors can be helpful when targeting for promotion of the service. Over 200 extended campus classes are taught each semester. The program area covers 27 counties in Kentucky. A predominance of reference assistance requests from a certain course may indicate a need for bibliographic instruction in that area. Comparisons of periods of peak usage can be drawn, as well as of preferred methods of document delivery. Original completed request forms are filed by month, then grouped within each month by the four extended campus centers (Fort Knox, Glasgow, Owensboro, and Russellville). Usage of ECLS by centers can be examined and compared. Requests for reference assistance are forwarded to librarians who assign a reference assistance log number and take the requests to reference to search indexes for citations to requested information. Clear explanations of students' subjects should be taken when the call is received, but sometimes a call-back must be made by the librarian for clarification. Even a small detail like the time zone of the requestor's address is important, because most of the return calls take place in the evenings.

Western Kentucky University was one of the first institutions in Kentucky to establish special library services for extended campus students. Other libraries in the state have since begun similar programs. We have been asked to share copies of our ECLS request form and to help others create their own.

Autbor's note: For additional information about WKU Libraries extended campus services consult: Michael B. Binder and others, "The Development of Off-Campus Library Services at Western Kentucky University," in Off-Campus Library Senvices Conference Proceedings (Mount Pleasant, Mich.: Central Michigan Press, 1988), p. 43-50; and Sally Ann Strickler and others, Report of the Task Force on Providing $L i$ brary Services to Extended Campus Students, Report No. IR 052668 (Bowling Green, Ky.: Western Kentucky University, 1987), available as ED 304159.

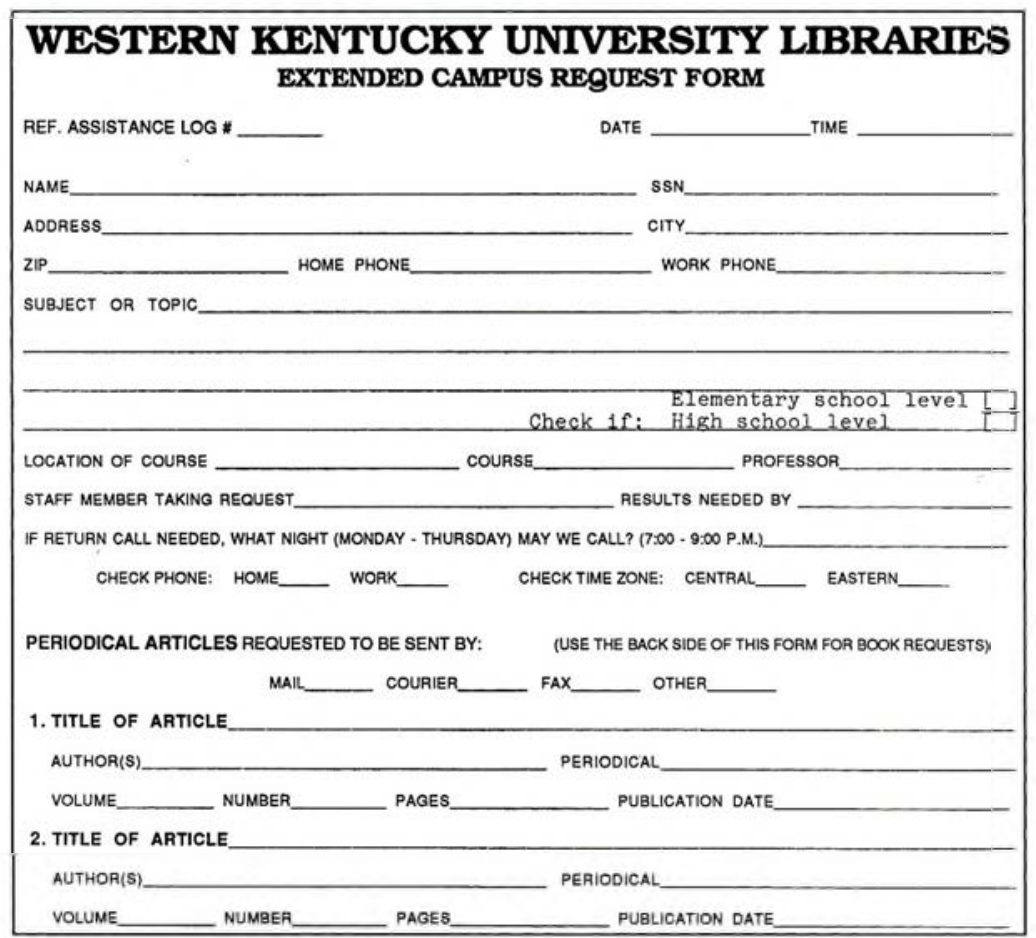

Figure 1. This part of WKU's request form shows key data needed. 